
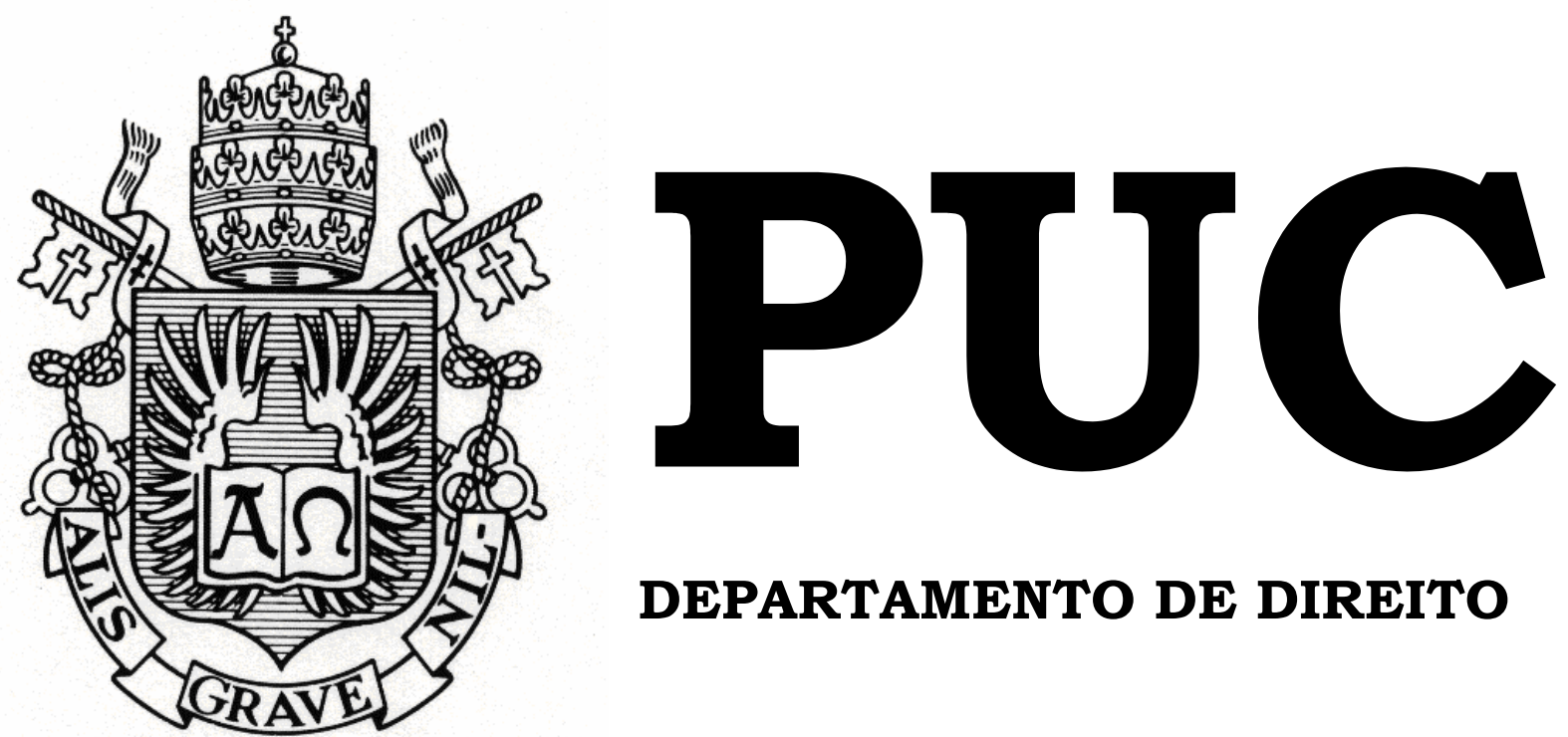

DEPARTAMENTO DE DIREITO

\title{
Cláusula Compromissória nos Contratos de Sociedade
}

por

Diego Mattos Osegueda

orientador: Lauro da Gama de Souza Júnior

2005.1

PONTIFÍCIA UNIVERSIDADE CATÓLICA DO RIO DE JANEIRO

RUA MARQUÊS DE SÃO VICENTE, 225 - CEP 22453-900

RIO DE JANEIRO - BRASIL 


\title{
Cláusula Compromissória nos Contratos de Sociedade
}

\author{
por
}

Diego Mattos Osegueda

Monografia apresentada ao
Departamento de Direito da
Pontificia Universidade
Católica do Rio de Janeiro
(PUC-Rio) para a obtenção do
Título de Bacharel em Direito.

Orientador: Lauro da Gama de Souza Júnior 
"O presente estudo poderia ser dedicado às diversas pessoas que contribuíram a minha formação pessoal e profissional, mas todas essas não teriam tido essa oportunidade de me ajudar, se fosse meu querido avô, JEREMIAS FERREIRA DE MATTOS, a quem o presente, o passado e futuros dias são integralmente devidos, obrigado Jerê. 


\section{INDICE}

\section{Resumo}

Introdução

2 - Da autonomia da vontade e as garantias constitucionais

3- Conceituação do Contrato de Sociedade da Clausula Compromissória 
3.3 - Da relação direta entre a Clausula Compromissória e o Contrato de Sociedade

3.3.1. - Autonomia da clausula compromissória ao 36

3.3.2. - Da natureza parassocial da clausula compromissoria estatutária 38

4-Dos Efeitos em relação as partes no contrato de sociedade

4.1- Do instrumento de constituição da sociedade

2.1- Das demais hipóteses

44

5 - Conclusão

48

Bibliografia 


\section{Resumo}

O presente estudo busca elucidar questões atinentes aos efeitos da clausula compromissória inserida nos contratos de sociedade, com especial atenção àquelas organizadas na forma da Lei 6.404/76, em função do crescimento do instituto da arbitragem no direito brasileiro e a possibilidade de instauração do juízo arbitral em conflitos societários, prevista no Art. 109 da Lei das S.A. após a reforma operada pela Lei 10.303/02.

Pesam argumentos consistentes tanto pela necessidade de expressa anuência à clausula por parte do sócio ou acionista, suportados nos da ordem pública, do direito subjetivo de ação e acesso ao judiciário previstos no Art. $5^{\circ}, \mathrm{XXXV}$ da $\mathrm{CR} / 1988$, renúncia essa que se vale da estrita interpretação prevista no Código Civil, os quais também fundamentam o presente.

Em sentido diverso, suportado, principalmente, no princípio do interesse comum da sociedade e na contraposição à argumentação de que a opção pela arbitragem não representa renúncia a direito essencial, juristas de respeitável alcunha acreditam ser desnecessária a expressa manifestação de concordância à clausula compromissória, pelo fato da existência desta no contrato da sociedade ser oponível perante a todos os sócios.

Questões sobre a equiparação dos contratos de sociedade aos da espécie "adesão" haja vista a específica previsão dada ao tema na Lei 9.307/96.

Legislações e jurisprudências estrangeiras também serão apontadas, com objetivo de melhor ilustrar a presente estudo, haja vista a problemática não ser exclusividade do ordenamento jurídico nacional, sendo, inclusive trata-se em lei específica pelo legislador italiano. 
Ao final, espera-se demonstrar ser a posição defendida a que melhor expressa os princípios orientadores no ordenamento nacional, ressalvando que não se trata de campo pacífico de interpretação diversa a aqui defendida, principalmente em função das mutações que vêm ocorrendo no âmbito internacional, razão pela qual acredita-se somente quanto da apreciação dos tribunais superiores, ter-se-á pacificada a matéria, sob a égide da ordem pública. 


\section{INTRODUÇÃO}

Desde de 1996 com advento da Lei de 9.307/96 que atribuiu força de título judicial ao laudo arbitral, bem como equiparou os árbitros à juizes de direito em sua competência para prestação jurisdicional, o direito brasileiro teve reincorporado ao seu ordenamento, um eficaz mecanismo para solução de conflitos que tenham como objeto, direitos patrimoniais disponíveis, qual seja, a jurisdição Extra-Judicial Arbitral, relativizando, em parte, o monopólio estatal na mediação e solução de controvérsias.

O mencionado instituto fez sua re-estréia no ordenamento jurídico nacional, após cair no ostracismo ao final do século XIX, ocasião em que a clausula compromissória passou a ser tratada como mero "compromisso em contratar", negando-lhe força executiva e coercitiva, passível de resolver-se em "perdas e danos" nos termos Lei Civil.

Com o novo status atribuído ao laudo arbitral na nova lei, questões atinentes à preservação dos direitos essenciais do indivíduo, como aquele insculpido no Art. $5^{\circ}$ XXXV da Constituição da República de 1988 - "a lei não excluirá da apreciação do judiciário lesão ou ameaça a direito" transformaram-se, primeiramente, em objeto de apreciação sobre a constitucionalidade da Lei de Arbitragem, já superada, operando desde então como limitador do campo de incidência do pacto arbitral.

Dessa forma, o objetivo do presente estudo será demonstrar os efeitos clausula compromissória às partes nos contratos de sociedade, em especial àquelas organizadas na forma da Lei 6.404 de 1976, haja vista a inclusão do $\$ 3^{\circ}$ no Art. 109 após a reforma ocorrida em 2002, e a problemática em relação aos efeitos perante os sócios, que acredita-se, deve dar-se de forma expressa e inequívoca, tema sob controvérsias na doutrina e de limitado precedente nos Tribunais Superiores. 
Serão abortados aspectos das searas societária, cível e processual até os limites impostos no plano constitucional, dada a pluralidade elementos nas relações envolvidas com a clausula compromissória nos contratos de sociedade.

Procurar-se-á demonstrar, no campo das relações societárias, especialmente sob a ótica apresentada por Modesto Carvalhosa e Pedro A. Batista Martins, autores de posição antagônicas que melhor enfrentaram o tema até a presente no âmbito nacional, que a ausência de adesão expressa à provocação do juízo arbitral extravasará o princípio da autonomia da vontade da parte, haja vista a natureza de renúncia a garantia constitucional em que consiste a Arbitragem, ferindo o princípio do livre acesso à prestação jurisdicional estatal, minando os pressupostos de validade do laudo arbitral, dentro dos limites em que a ordem pública é imposta nos Tribunais Superiores.

\section{Capítulo I - Arbitragem e o Direito Societário}

Inicialmente, cabem algumas considerações sobre a evolução histórica do instituto da arbitragem no plano jurídico nacional, seus aspectos motivadores e seu desenvolvimento nos ordenamentos estrangeiros, para que então se passe a analise detalhada das questões pertinentes a um dos pontos de partida para instauração da jurisdição arbitral, qual seja, a adesão à clausula compromissoria.

Conforme introduzido, o foco será as relações em sociedade, dada a particularidade e a multiplicidade de interesses e conceitos legais aplicáveis à seara societária. 
De antemão, se reconhece a necessidade do avanço e da estabilização do instituto da arbitragem no direito brasileiro. Porém, opina-se que esse avanço deve ocorrer sobre sólidos pressupostos de legalidade, a fim de se obstar razões que o levem novamente ao desuso quando da solução de conflitos societários.

\subsection{Evolução Histórica}

O instituto da Arbitragem se faz presente nas relações societárias desde 1850, pela edição do Código Comercial Brasileiro, que em seu Art. $294^{1}$, , determinava, de forma obrigatória, a instauração do juízo arbitral na solução de controvérsias sendo posteriormente regulado pelo Art. 411 do Decreto n 737 de 1850 que diferenciava a arbitragem compulsória da facultativa.

A obrigatoriedade de instauração do juízo arbitral nesses conflitos produziu efeitos por dezesseis anos, lançado-se no campo do desuso com advento da Lei 1.350/1866, até que chegasse seu ponto final, conseqüência do Decreto 3.900/1867, o qual tratou-se pela primeira vez no Brasil a cláusula compromissória como mero compromisso de contratar, passandolhe a negar força executiva e coercitiva.

Não obstante ao tratamento dado à clausula compromissória, o mesmo decreto criou a possibilidade de se recorrer judicialmente do laudo arbitral $^{2}$ em seu mérito. Sem força para vincular as partes e, podendo o laudo ser objeto de revisão judicial, não tardou o instituto da arbitragem brasileiro a cair no ostracismo.

\footnotetext{
${ }^{1}$ Art. 294 - Todas as questões sociais que se suscitarem entre sócios durante a existência da sociedade ou companhia, sua liquidação ou partilha, serão decididas em juízo arbitral."

${ }^{2}$ Decreto 3.900/1867 - Art. 62: Se o compromisso não tiver a clausula sem recurso, appellando alguma das partes, será a causa decidida em $2^{\mathrm{a}}$ instância pela forma e modo porque são julgadas as causas da jurisdição ordinária".
} 
O Código Civil de 1916 nos arts. 1.037 a 1.048 voltou a tratar do tema. Nele ficava previsto que a clausula compromissória deveria ser avençada por escrito e o laudo arbitral ficaria sujeito à homologação judicial para atingir força coercitiva.

A doutrina da época manteve o entendimento de que se tratava a clausula compromissória de mera promessa em contratar ${ }^{3}$, devendo-se resolver as controvérsias decorrentes de seu descumprimento via perdas e danos $^{4}$

Somente com ante-projeto de Lei 78/92, que viria ser conhecido pela alcunha do Exmo. ex-presidente Marco Maciel, responsável por sua apresentação ao Congresso Nacional, a arbitragem voltaria a seu papel de destaque, com a posterior transformação deste na Lei 9.307/96 - Lei de Arbitragem.

Em sintonia com as razões apontadas para o desuso histórico da Arbitragem no Brasil até aquela data, o relator do Projeto Marco Maciel, Exmo. Senador Antônio Mariz, assim dispôs em seu parecer:

"Lembra que a legislação brasileira sobre arbitragem não permite seja o instituto por dois grandes motivos: primeiro por falta de previsão legal para a clausula compromissoria, o que torna a promessa de solução arbitral letra morta nos contratos; em segundo lugar a necessidade de homologação do laudo arbitral pelo Poder Judiciário."

Estes pontos vieram por ser dirimidos nos $4^{\circ}$ e 18 respectivamente, que dentre as inúmeras disposições da Lei de Arbitragem, sem dúvida constituíram como fatores fundamentais a revitalização do instituto.

\footnotetext{
3 VILELA, Marcelo Dias Gonçalves. Arbitragem no Direito Societário. Belo Horizonte. Mandamentos p (apud). BENVILÁQUIA, Clóvis. Código Civil dos Estados Unidos do Brasil. 2. Ed. Rio de Janeiro: Francisco Alves, v. 4.

4 VILELA, Marcelo Dias Gonçalves. Arbitragem no Direito Societário. Belo Horizonte. Mandamentos: (apud) MOREIRA, José Carlos Barbosa. Juízo Arbitral: clausula compromissória, efeitos. In: Temas de direito processual: segunda série. São Paulo: Saraiva, 1990, p. 192-209.
} 
Outra disposição que merece destaque, introduzida também pelo Art. 18 da Lei 9.307/96, foi a equiparação dos árbitros a juizes estatais quando da apreciação do mérito e do dever de imparcialidade.

Válido é abrir um parêntese para comentar o mau uso da elevação de pessoas comuns à condição de arbitro que instituições de arbitragem de caráter duvidosos, que inclusive utilizam, na "carteira de arbitro", uma roupagem similar àquela usada pelos juízes de direito do poder estatal, vêm dando. Imperfeições do ser humano que a lei não pôde evitar.

Revigorada e em pleno crescimento a Arbitragem, com disposto Art. $31^{5}$ da Lei, é, sem dúvida, um dos temas de maior atenção na doutrina nacional, suscitando debates e estudos, como o que se leva no presente.

\subsection{Arbitragem nas legislações estrangeiras}

Conforme bem assinalado pelo Prof. Marcelo Dias Gonçalves Vilela em sua obra intitulada "Arbitragem e o Direito Societário", "A (sic) história da arbitragem no direito brasileiro, sobretudo em relação aos conflitos comerciais, guarda correspondência com a evolução da arbitragem em outros paises, em especial Espanha e França”.

O Código Comercial Francês de 1807 em seu artigo 51 instituía a arbitrage force às sociedades de capitais ${ }^{6}$, que viria a ser copiada pelo legislador nacional no Código Comercial de 1850.

A obrigatoriedade no direito francês perdurou até a "Loi dês 17 et juillet 1856" que atribuiu competência originária ao Tribunal de Comércio

\footnotetext{
${ }^{5}$ Art. 31. A sentença arbitral produz, entre as partes e seus sucessores, os mesmos efeitos da sentença proferida pelos órgãos do Poder Judiciário e, sendo condenatória, constitui título executivo.
} 
quando da solução de conflitos, bem como abriu possibilidade a utilização da arbitragem facultativa. Nota-se evidente intenção do legislador nacional da época em seguir a esteira das legislações européias, mais experimentadas em questões comerciais, seguindo quase que simultaneamente o calendário francês.

No mesmo caminho seguia a legislação espanhola. O Código de Comércio de Sainz e Andino de 1829 previa o juízo arbitral obrigatório para solução de controvérsias societárias, cabendo recurso apenas naquelas fundadas em questões de direito, sendo irrecorríveis quando versassem sobre usos comerciais ou na eqüidade.

A partir de 1868, com a unificação dos foros ocorrida na organização judiciária espanhola, restou apenas a Ley de Enjuiciamento Civil de 1855regulando a matéria, na qual eram previstas apenas a modalidade facultativa de arbitragem, admitindo ainda espécies de recurso contra o mérito das decisões arbitrais ${ }^{7}$.

No que tange a abolição do juízo arbitral obrigatório, o ordenamento jurídico nacional se antecipou ao espanhol que veio por derrogá-lo apenas 1885 com a edição neste ano de um novo Código do Comercio.

Voltando a esfera francesa, a Corte de Cassação em 1843 proferiu importante decisão, que mais adiante quando das considerações sobre a natureza da clausula compromissória será tratada, na qual negava-se pela primeira vez força coercitiva a clausula arbitral, fundamentada na impossibilidade de se delimitar os limites de eventuais litígios que seriam abarcados por esta, bem como a forma de nomeação dos árbitros.

${ }^{6}$ STRENGER, Irineu. Autonomia da Vontade, $-2^{\text {a }}$ Ed. São Paulo: LTR (apud) COHEN, Daniel. Arbitrage et societé. Paris: LGDJ, 1993, p. 7.

${ }^{7}$ STRENGER, Irineu. Autonomia da Vontade,- $2^{\text {a }}$ Ed. São Paulo: LTR (apud). LERA, Silvia Gaspar. El ambito de aplicación del arbitraje. Pamplona: Aranzadi, 1998. p. 42-43. 
Décadas adiante, com a aprovação do Protocolo de Genebra, a França modificou o art. 631 de seu Código Comercial reconhecendo a impossibilidade de se definir com exatidão os contornos do conflito na cláusula compromissória, óbice ao instituto da arbitragem que perdurava desde a supra citada decisão, passando-se desde então a se aceitar limites genéricos ou determináveis.

Atualmente, após a modificação do Art. 2061 do Código Civil Francês, a arbitragem vem se consolidando nos conflitos cíveis e comerciais, ficando, porém, condicionado o laudo arbitral a um exequatur dentro do Poder Judiciário:

"Code de Procédure Civile, Article 1477. La sentence arbitrale n'est susceptible d'execution forcéequ'em vertu d'une décision d'exequatur émanant du tribunal de grande instance dans le ressort duquel la sentence a été rendue"

$\mathrm{Na}$ Espanha, a consolidação do juízo arbitral deu-se por conseqüência da Lei 36/1988, que limitou os recursos contra o laudo arbitral, anteriormente previstos, atribuindo a este força de título judicial, idêntico ao adotado pelo legislador nacional.

Recentemente foi aprovada a Lei 60/2003, a qual se conhece como a nova Lei de Arbitragem espanhola, que aprimorou alguns instrumentos sobre a autonomia das partes, prestigiando-a.

Sendo muitos os pontos de tangencia entre a legislação arbitral nacional e a evolução histórica dada nos países citados, pode-se concluir que a Lei 9.307/96 é um exemplo de atualidade e sintonia legal com o tema, servindo como instrumento sólido ao fortalecimento que se espera da Arbitragem no Brasil. 


\subsection{Elementos motivadores a adoção do juízo arbitral}

Os argumentos em favor da consolidação da arbitragem no Brasil, transitam, de modo geral, sob os aspectos da agilidade, tecnicidade e custo, somado a maior proteção à eventuais fraudes na jurisdição estatal, muitas vezes vista com desconfiança por investidores estrangeiros, proporcionados pelo referido instituto.

No que tange ao aspecto da agilidade, logo em seu Art. 23, a Lei de 9.307/96 determina que:

\footnotetext{
"A sentença arbitral será proferida no prazo estipulado pelas partes. Nada tendo sido convencionado, o prazo para a apresentação da sentença é de seis meses, contado da instituição da arbitragem ou da substituição do árbitro." (grifo aditado)
}

Com certa habitualidade, apenas a fase de composição da lide, que se estende do despacho citatório ao saneador, em controvérsias envolvendo conflitos entre sócios, supera em muito o prazo legal para entrega do laudo arbitral, salvo estipulação em contrário.

Não pairam, portanto, dúvidas que o proferimento da decisão final na via arbitral, se dará lapso temporal consideravelmente inferior ao dispensado na jurisdição estatal em todas suas instâncias, o que contribuirá por minorar os efeitos que as longas demandas judiciais causam ao patrimônio das sociedades, em especial aos valores mobiliários daquelas que possuem capital aberto a negociação no mercado de valores.

Outro argumento muitas vezes mencionado é o da tecnicidade da sentença arbitral, pois se pressupõem que esta será emanada por pessoa qualificada no tema objeto da controvérsia, o que não se pode esperar da jurisdição estatal, onde o magistrado tem que lidar diariamente com as mais variadas matérias, sendo impossível manter-se atualizado a todas. Seria 
equiparável a exigir de um médico clínico geral, um diagnóstico preciso de uma mazela cerebral.

Considere ainda, que as relações societárias possuem maior dinâmica em relação a outras áreas do direito, pois moldada sob influencia de legislações e jurisprudência de outros Estados, esta sofre constantes mutações, logo, a opção pelo juízo arbitral ganha papel fundamental para segurança dos interesses envolvidos.

Questões que vão além da relação sócio e sociedade e chegam a terceiros, como àqueles referentes ao "segredo industrial", também encontram conforto no juízo arbitral, protegido um função de sua sigilosidade.

Um ponto que levanta maior atenção é quanto ao custo da jurisdição arbitral. Evidente que os valores praticados pelo Estado quando da provocação da atividade jurisdicional dificilmente superarão aos praticados nos tribunais arbitrais de maior credibilidade.

Porém no campo das relações societárias, o conceito "custo" não está ligado apenas aos valores diretamente expendidos na provocação da jurisdição. Considerar-se-ão também toda gama de efeitos que a lentidão do Poder Judiciário e sua potencial falta de tecnicidade podem causar ao valor de avaliação de determinada sociedade. Nessa área, a máxima popular do "tempo é dinheiro", encontra seus maiores defensores. Longas demandas judiciais podem conter um custo oculto incalculável.

Há quem complemente os argumentos acima citados, como sendo o juízo arbitral um fator de redução do "Risco Brasil", por retirar a solução da controvérsia na jurisdição estatal, sempre abalada por indícios ou denuncias poucos escusas. 
Sendo as quotas ou ações o fator primordial para avaliação de uma sociedade, a adoção do juízo arbitral atuará como fator de valorização deste, bem como aos conceitos de governança corporativa. Para melhor ilustrar, basta uma breve observação os mecanismos de governança corporativa adotados na BOVESPA ${ }^{8}$, que se verá uma melhor classificação daquelas companhias que adotam a clausula compromissória em seus contratos.

Isto posto, a controvérsias advindas de relações societárias, dentro dos limites dos chamados direitos patrimoniais disponíveis ${ }^{9}$, estarão definitivamente melhor abarcadas, pelo que, acreditasse inequivocamente no fortalecimento deste instituto.

\section{Capítulo II - Da Autonomia da Vontade e a garantia a prestação jurisdicional estatal}

Conforme de buscará demonstrar adiante, a escolha do juízo arbitral que tem em sua origem o campo de incidência da autonomia da vontade, se caracteriza como uma renúncia ao direito constitucional à prestação jurisdicional estatal, merecendo, portanto, tratamento cauteloso quanto à sua instauração.

Logo, nascendo da vontade do indivíduo o compromisso em adotar o procedimento arbitral para solução de controvérsias, mesmo ainda em potencial, como representa a clausula compromissoria, dependerá esta de inequívoca manifestação da vontade da parte, o que não se pode

\footnotetext{
${ }^{8}$ Bolsa de Valores do São Paulo - São previstos no regulamento dos Níveis de Governança Corporativa condição a classificação em Nível 2 e Novo Mercado a adesão à Câmara de Arbitragem para solução de conflitos societários.

${ }^{9}$ Lei $9307 / 96$, Art. $1^{\circ}$ As pessoas capazes de contratar poderão valer-se da arbitragem para dirimir litígios relativos a direitos patrimoniais disponíveis.
} 
caracterizar apenas pela intenção do indivíduo ao adentrar em determinada sociedade.

\section{1 - Da Autonomia da Vontade}

A filosofia se ocupou durante longo período a definir os contornos da existência da "vontade" no comportamento do indivíduo. Dizia Descartes que a vontade consiste em que, para afirmar ou negar, perseguir ou fugir dessas coisas que o entendimento nos propõe, agimos de tal sorte que não percebemos ou sentimos se alguma força exterior existe a nos constranger ${ }^{10}$.

$\mathrm{Na}$ obra intitulada "Autonomia da Vontade" o Prof. Irineu Strenger cita o filósofo alemão Karl Jaspers ao dizer:

"Jaspers com genial acuidade evidencia que todas as ações de uma vida cotidiana são importantes porque, queridas ou não, tem uma ação plastificadora, formadora e, assim, a conseqüência da vontade atribuível a ela empiricamente é, portanto, não só a ação momentânea sob as condições dadas pelas disposições caracterológicas naturais e os mecanismos extraconscientes, mas também a aptidão adquirida no atuar ${ }^{11}$,

Ainda no campo da filosofia do direito, Miguel Reale assinala com propriedade "no sentido de mostrar que o homem não é portador de razão, nem tampouco um ser que só pela razão logra atingir o conhecimento” ${ }^{12}$ porquanto há certos acontecimentos que só se conhecem plenamente através dos elementos que a afetividade, a vontade ou a intelecção pura nos fornecem.

\footnotetext{
10 STRENGER, Irineu. Autonomia da Vontade,- 2a Ed. São Paulo: LTR. P. 24 (apud) DESCARTES, Meditations, $I V, 7$.

${ }^{11}$ STRENGER, Irineu. Autonomia da Vontade,-2a Ed. São Paulo: LTR. p. 26.

${ }^{12}$ STRENGER, Irineu. Autonomia da Vontade,- $2^{\mathrm{a}}$ Ed. São Paulo: LTR, 2000. (apud) REALE, Miguel. Filosofia do Direito. 4ª Edição. São Paulo, 1965, p. 125
} 
Etimologicamente, a autonomia significa capacidade de reger-se por si mesmo, ou capacidade de agir espontaneamente. Latu sensu a autonomia pode ser entendida como a condição de um indivíduo ou a coletividade escolher por si mesma a lei e as regras as quais se submeterão.

Somando aos conceitos acima, o pensamento Kantiano sobre a autonomia da vontade indica esta como "uma propriedade mediante a qual a vontade constitui uma lei por si mesma, independentemente de qualquer propriedade dos objetos do querer. ${ }^{13}$,"

No mesmo sentido, "a autonomia da vontade quer representar a possibilidade de um auto-regramento dos próprios interesses do individuo, enfim, a possibilidade de constituir a vontade pela qual para si mesma uma $l e i^{14,}$.

Adentrando-se especificamente no campo do direito, Vicente Ráo aponta a vontade como elemento constituinte básico da teoria do direito e da realidade jurídica. Em suas próprias palavras ${ }^{15}$ :

"a vontade, manifestada ou declarada, possui no universo jurídico poderosa força criadora: é a vontade que, através de fatos disciplinados pela norma, determina a atividade jurídica das pessoas e, em particular, o nascimento, a aquisição, o exercício, a modificação ou a extinção dos direitos e correspondentes obrigações, acompanhando todos os momentos e todas as vicissitudes destas e daquelas."

Georges Renard adepto a corrente que classifica a vontade no direito positivo como um sistema de regras que dirigem a atividade tanto dos

13 STRENGER, Irineu. Autonomia da Vontade,- $2^{\mathrm{a}}$ Ed. São Paulo: LTR, 2000. (apud) VLESCHAUWER, Herman J. de. La evolución del pensamento Kantiano - Historia de una Doctrina. México: 1962, cf. Ferrater Mora, verbete "Voluntad", in Diccionario de filosofia, $4^{\mathrm{a}}$ Ed., 1958.

${ }^{14}$ STRENGER, Irineu. Autonomia da Vontade,- $2^{\mathrm{a}}$ Ed. São Paulo: LTR, 2000 (apud) KANT, Emmanuel. Fundamentos da metafisica dos costumes. Tecnoprint. 1990 p. 92.

${ }^{15}$ STRENGER, Irineu. Autonomia da Vontade, $-2^{\mathrm{a}}$ Ed. São Paulo: LTR, 2000 (apud) Ráo, Vicente. Ato Jurídico, São Paulo. 1961. 
particulares como dos agentes do Estado, regras essas que se não passam de uma tradução do direito natural e da moral social, afirma que o direito positivo só pode ser estudado como uma direta manifestação da vontade ${ }^{16}$ :

"é evidente que é a vontade humana que traduz as sugestões ideais do direito natural nas realidades no meio social (...) pois sempre é a vontade de seu autor a que situa um ato jurídico ou material na ordem de seus assuntos ou na ordem dos assuntos de seu tutelado ou de seu mandante ou na ordem de assuntos de uma das associações, corporações ou instituições que ele representa"

Dessa forma, a autonomia da vontade como lei entre as partes terá no plano contratual e obrigacional papel fundamental na definição das normas que incidirão sobre determinado negócio jurídico, ultrapassando os limites da lei interna, se for o caso, com limites impostos apenas pela ordem pública.

No mesmo sentido, ensina a ilustre Professora dessa Universidade Nadia de Araújo que ${ }^{17}$ :

"A autonomia da vontade desenvolve os seguintes papéis no direito internacional privado: um primeiro, como meio privilegiado de designação da lei estatal aplicável a um contrato, após, como subtração do contrato ao direito estatal do foro e, finalmente, como eliminação do conflito de leis"

Sob esse aspecto da vontade das partes fundamenta-se a arbitragem em atribuir faculdade às partes envolvidas em conflitos, existentes ou potenciais, de subtrair da jurisdição ordinária a apreciação e o julgamento, buscando no foro privado a prestação jurisdicional.

\footnotetext{
${ }^{16}$ SILVA, Eduardo Silva da. Arbitragem e Direito da Empresa. São Paulo: RT (apud) RENARD, Georges. Le droit, la justice et la colonté. Paris, 1924.

${ }^{17}$ SILVA, Eduardo Silva da. Arbitragem e Direito da Empresa. São Paulo: RT (apud) Araújo, Nádia. A nova lei de arbitragem brasileira e os princípios uniformes dos contratos internacionais - p. 96-107.
} 
É limitação primordial ao exercício dessa faculdade, estar o objeto da controvérsia, dentro dos limites dos chamados "direitos patrimoniais

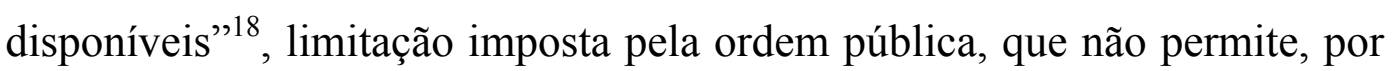
exemplo, que conflitos do Direito de Família sejam arbitráveis.

Dessa forma não poderão existir quaisquer incertezas sobre a intenção da parte em adentrar no juízo arbitral, sob pena de se macular a autonomia da vontade. Nesse sentido, destaca do Exmo. Ministro Sepúlveda Pertence quando do julgamento da Sentença Estrangeira Contestada 6757-7 Reino Unido:

"Em que pese não se exija, ao menos segundo a lei nacional, uma forma solene rígida para clausula compromissória, é essencial que o ajuste, além de escrito, suja de uma comunhão de vontades. Adimite-se, é certo, sua convenção mediante troca de correspondência, telegrama, facsimile, ou outro modo expresso qualquer, desde que, conforme assevera Carreira Alvim "comprovada a proposta de uma das partes e a aceitação da outra". (grifo aditado)

Voltando ao foco do presente estudo, não se pode admitir que o simples ingresso de um sócio ou acionista em uma sociedade que possua a clausula arbitral, signifique sua vontade de submeter-se ao juízo privado.

Evidente que a manifestação da vontade pode ser caracterizada de outras formas que não seja apenas a expressa adesão a disposição contratual. Se, um sócio ou acionista, em determinado momento ingressa no juízo arbitral em matéria referente a sociedade a qual faz parte, difícil seria este de escusar da participação de outros juízos arbitrais posteriores, mesmo sob a alegação de não ter firmado a clausula compromissória. Seria espécie de venire contra actum proprium.

\footnotetext{
${ }^{18}$ Lei $9307 / 96$, Art. $1^{\circ}$ As pessoas capazes de contratar poderão valer-se da arbitragem para dirimir litígios relativos a direitos patrimoniais disponíveis Lei 9307/96, Art. $1^{\circ}$ As pessoas capazes de contratar poderão valer-se da arbitragem para dirimir litígios relativos a direitos patrimoniais disponíveis
} 
Vale, portanto, a manifestação da vontade seja direta ou indireta, mas dúvidas não poderão existir. A Convenção de Nova Iorque que entrou em vigor no território nacional por meio do Decreto 4.311/02 assevera que:

Artigo II. 2 - Entender-se-á por "acordo escrito" uma clausula arbitral inserida em contrato ou acordo de arbitral, firmado pelas partes ou contido em trocas de cartas ou telegramas"

Recentemente quando da apreciação de sentença estrangeira e sua respectiva homologação, o Exmo. Min. Carlos Alberto Meneses Direito e a Corte Especial do Superior Tribunal de Justiça, entenderam por deferir a pedido em linha com fundamento acima exposto: (obs.: decisão ainda não publicada):

\section{SENTENCAA ARBITRAL ESTRANGEIRA. CLÁUSULA COMPROMISSÓRIA. CONTRATO. ASSINATURA.}

A Corte Especial deferiu o pedido de homologação de sentença arbitral ao entendimento de que é possível a cláusula compromissória tácita quando a parte compareceu ao processo de arbitragem e não impugnou sua existência. No caso, considera-se preenchido o requisito ao ter sido aceita a convenção de arbitragem, de acordo com a prova dos autos, ao manifestar defesa no juízo arbitral, sem impugnar oportunamente a existência da cláusula compromissória. SEC 856-EX, Rel. Min. Carlos Alberto Menezes Direito, julgado em 18/5/2005. (grifos aditados).

Outros aspectos pesam na eficácia da instância arbitral além da clara manifestação da vontade, como os referentes à natureza de renúncia ao juízo ordinário, garantia constitucional do indivíduo, que, assim como a ordem pública, dará contornos ao tema apresentado, como se passa a demonstrar. 


\section{2 - A Arbitragem como Renúncia a Garantia Constitucional}

Muito se discutiu sobre a constitucionalidade da Lei 9.307/96, sob os aspectos das garantias ao direito de ação, contraditório e ampla defesa, porém, outra conclusão não poderia ter chegado nossa Suprema Corte, se não pela plena validade da norma.

Superada a análise da constitucionalidade, não se pode esquecer que o juízo arbitral, apesar de em perfeita harmonia com norma constitucional contida no Art. $5^{\circ}$ XXXV da Carta Magna de 1988, trata-se de exceção ao principio prestação jurisdicional estatal - garantia de direito definida por Nelson Nery Jr. como "um direito subjetivo à sentença" os princípios da autonomia da vontade acima expostos.

José Afonso da Silva em sua obra Curso de Direito Constituional Positivo ao tratar do tema, ensina que "O (sic) princípio da proteção judiciária, também chamado princípio da inafastabilidade do controle jurisdicional, constitui em verdade, a principal garantia dos direitos subjetivos". ${ }^{20}$

Determina o aludido dispositivo legal que "a lei não excluirá da apreciação do judiciário lesão ou grave ameaça ao direito”, mas as partes poderão. Dessa forma, a parte, além de manifestar sua vontade pela adoção do juízo arbitral, dispõe, renuncia a garantia constitucional prestação jurisdicional estatal, pois se assim não fosse, haveria uma competência concorrente, em sentido oposto ao objetivo do legislador ao editar Lei de Arbitragem, bem como ao das partes signatárias do pacto arbitral.

\footnotetext{
${ }^{19}$ NERY JR, Nelson. Princípios do processo civil na constituição federal. São Paulo: Revista dos Tribunais, 1994 - p. 91.

20 Silva, José Afonso da. Curso de Direito Constitucional Positivo. 16 Edição. São Paulo: Malheiros, 2003. (apud) WATANABE, Kazuo. Controle jurisdicional, p. 7; in. Ada Pellegrini Grinover, As garantias constitucionais do Direito de Ação.São Paulo. p 133
} 
O Exmo. Min. Sepúlveda Pertence ao tratar sobre o tema no voto da SE 5206 - AgR. ensina que:

"Com a instituição do juízo arbitral, por ato das partes, nota Biamonti (ob. Loc. Cits. P.900 "si attua (...) uma espressa rinunzia alla cognizione di uma op piu controversie da parte del guidice, al quale le vertenze stesse vengono sottrate"

Seguindo no mesmo voto:

"A constitucionalidade do juízo arbitral - perdoese a insistência - deriva da renunciabilidade, no caso, do exercício do direito de ação - que é reflexo subjetivo da garantia da prestação jurisdicional, insculpida hoje no art. $5^{\circ} \mathrm{XXXV}$, da Lei Fundamental - relativamente a uma pretensão material disponível"

Válido abrir um parêntese para discordar quanto a renunciabilidade do direito de ação. Opina-se que a renúncia fica restrita a prestação jurisdicional, haja vista que o direito de ação é garantido, por via transversa, na jurisdição arbitral.

O mesmo raciocínio já era adotado por Pontes de Miranda ao dizer que: “o compromisso é renúncia ao juízo estatal, a processualidade estatal da relação jurídica entre as partes e a pessoa que tem, em virtude de seu estatuto, a cognição."21

Ainda, Modesto Carvalhosa afirma que "fundamentalmente o juízo arbitral advém de renúncia a direito essencial do pactuante”.

Essas considerações ganham importância ao adentrar-se na esfera da interpretação a ser dada a "renúncia" em conformidade com a Lei 10.402/02 como se verá no próximo capítulo.

\footnotetext{
${ }^{21}$ MIRANDA, Pontes de. Comentários ao Código de Processo Civil. Rio de Janeiro: Ed. Forense, 1977 XV p. 240.
} 


\section{Capítulo III - Conceituação do Contrato de Sociedade e da Clausula Compromissória}

Para que se tenha melhor demonstrada a tese da necessidade de expressa anuência à clausula compromissória ora defendida, mister se faz somar as considerações sobre a autonomia da vontade ao enquadramento do referido pacto arbitral e seu veículo de aplicação às partes em uma sociedade de capital, o contrato de sociedade.

As limitações ao exercício da autonomia da vontade imposta pelas garantias fundamentais, expostas no capítulo anterior, terão papel fundamental na interpretação na ótica pela qual deve ser encarada a clausula compromissória estatutária. Isso porque a decisão arbitral, apesar de todos as positividades acima aduzidas sobre a jurisdição arbitral, pode resultar em atentado ao direito do indivíduo, ou mesmo transformar-se em mecanismos de abuso de poder nas sociedades de capital, minando as alternativas de defesa do acionista.

\section{1- Da Clausula Compromissória}

Inicialmente, cumpre delimitar que a polêmica quanto a imposição do juízo arbitral ao acionista, gira em torno dos efeitos da clausula compromissória inserida no estatuto da sociedade. Não se faz necessário entrar nas definições do compromisso arbitral instaurador do juízo, pois este, se expressamente provocado pelo acionista que não aderiu a cláusula terá plena eficácia.

A discussão é se o compromisso arbitral, quando provocado contra acionista que não anuiu expressamente a clausula, terá eficácia para 
vincular a parte, ou mesmo para fundamentar a ação prevista no Art. $7^{\circ}$ da Lei $9.307 / 96^{22}$, ou, ainda, se será matéria pacível à nulidade do laudo arbitral prevista nos termos do Art. 32 da mesma Lei. Nesse sentido, a posição da obrigatoriedade de anuência expressa defendida, em especial, pelo mestre Modesto Carvalhosa será pedra angular ao desenvolvimento das seguintes considerações.

Inserem-se na Clausula Compromissória os elementos caracterizadores do negócio jurídico, definido no Art. 104 do Código Civil: "A validade do negócio jurídico requer: I - agente capaz; II - objeto lícito, possivel, determinado ou determinável; III - forma prescrita em lei”, sendo definida por Jose Eduardo Carreira Alvim em sua obra "Direito Arbitral", ao citar Leonardo Aravena Arredondo como:

“(...) ato mediante o qual as partes convencionam remeter a árbitros o conhecimento de todas ou algumas das questões que surjam, no futuro, entre elas, relativamente a matérias ou assuntos que assinalam, subtraindo-as dos tribunais de jurisdição ordinária." (Ed. Forense, p. 176)

A Lei de Arbitragem ainda em seu Art. $4^{\circ}$ atribui a natureza de pacto convencional ${ }^{23}$, assim como no código de processo civil francês:

"Art. 1442 - La clause compromissoire est la convetion par laquelle les parties à un contrat s'engagént à soumetree à l'árbitrage les litiges qui pourrant naître relavement à ce contrat"

22 “Art. $7^{\circ}$ Existindo cláusula compromissória e havendo resistência quanto à instituição da arbitragem, poderá a parte interessada requerer a citação da outra parte para comparecer em juízo a fim de lavrar-se o compromisso, designando o juiz audiência especial para tal fim".

${ }^{23}$ Art. $4^{\circ}$ A cláusula compromissória é a convenção através da qual as partes em um contrato comprometem-se a submeter à arbitragem os litígios que possam vir a surgir, relativamente a tal contrato. 
Dessa forma, a clausula compromissória será o meio válido pelo qual as partes se comprometerão na eventualidade do surgimento de controvérsias oriundas de um contrato, em abrir mão da garantia constitucional da prestação jurisdicional do estado em prol do juízo arbitral. Logo o objeto da clausula, assim como todo procedimento arbitral, advém de renúncia a direito essencial do pactuante, como anteriormente exposto, pelo que se trata de pacto personalíssimo inquestionavelmente declarado em seu aspecto formal, e que não se transmite por sucessão, cessão ${ }^{24}$.

Com efeito, ganha importância o que do texto do código civil em vigor ao determinar que "os negócios jurídicos benéficos e a renúncia interpretam-se estritivamente".

No mesmo sentido, o jurista espanhol Reglero Campos ${ }^{26}$ afirma:

“... siendo el arbitraje una institución por la cual
las partes renuncian a un derecho constitucional
fundamental con es el de la tutela efectiva de los Jueces e
Tribunales, es claro que tal renuncia debe hacerse de
forma expresa e inequivoca, de tal manera que al
voluntad de someterse a arbitraje no podrá inferirse de
los actos de las partes."

Não se trata, porém, de um juízo de exceção ou mesmo de atentado ao princípio da ampla defesa e do contraditório, pelo contrário, escolhida a jurisdição arbitral, esta transcenderá a vontade das partes e se constituirá como jurisdição contenciosa, fundamentada nos preceitos legais da legislação pactuada pelas partes.

O que se quer dizer é que o ingresso na jurisdição, por assim dizer-se não-estatal, prescinde de expressa aceitação da parte vinculada, por se tratar

\footnotetext{
${ }^{24}$ CARVAlhoSA, Modesto. Clausula Compromissória Estatutária. In Logo, Jorge (org.) Reforma da Lei das Sociedades Anonimas. $2^{\mathrm{a}}$ Ed. Rio de Janeiro: Forense., 2000. p. 322

${ }^{25}$ Lei 10.402/02, Art. 114.
} 
de renúncia a prestação jurisdicional ordinária, aquela garantida a qualquer indivíduo, em qualquer situação, quando lesado ou ameaçado em seu direito. Não se deve aceitar vinculação automática nos termos do Art. 111 do Código Civil, conforme defende a Ilma. Denise Barbosa Moreira em seu estudo sobre a matéria ${ }^{27}$, pelo simples fato da parte ter conhecimento da prévia existência do pacto arbitral do estatuto da sociedade ou mesmo de posterior inserção em alteração contratual.

Pedro A. Batista Martins ${ }^{28}$, uma das peças fundamentais no projeto de Lei Marco Maciel ainda defende que:

"Nada mais natural e justo que a fixação da arbitragem por modificação contratual legitimamente aprovada pela maioria de boa-fé e no interesse social gere expectativa na sociedade e nos demais sócios, diante da conduta do minoritário, da validade e eficácia da condição contratada. Ainda mais quando notamos que a lei de arbitragem, em momento algum, determina expressamente a assinatura da parte como requisito formal de validade da estipulação, ao contrário, o que exige é a forma escrita." (grifos aditados)

Tal fundamento é suportado no princípio do interesse comum da sociedade, pois supostamente a clausula arbitral age em favor da sociedade. Sustenta ainda a corrente que não entende necessária a expressa anuência à clausula compromissoria, que há apenas uma quebra ao monopólio estatal da prestação jurisdicional e não uma subtração à jurisdição, ficando resguardados os direitos essenciais do indivíduo.

"Quanto à clausula compromissória, aplicável o mesmo raciocínio: não se trata de renúncia a direito

\footnotetext{
${ }^{26}$ CAMPOS, Reglero. El arbitraje: convenio arbitral u lãs caudas de nulidad del laudo en la Ley de 5 de diciembre de 1988. Madrid: Montecorvo, 1991, p 83 apud MORENO, Faustino Cordón. El arbitraje en le derecho español: interno e internacional. Pamplona: Aranzadi, 1995, p. 61

${ }^{27}$ MOREIRA, Daniela Bessone Barbosa. A convenção arbitral em Estatutos e Contratos Sociais. P. 363-391, in ALMEIRA, Ricardo Ramalho. Arbitragem Interna e Internacional - Questões de Doutrina e da Prática. Rio de Janeiro: 2004: Renovar.

${ }^{28}$ MARTINS, Pedro A. Batista. A arbitragem nas sociedades de responsabilidade limitada in. Reflexões sobre arbitragem: in memoriam do Desembargador Cláudio Vianna de Lima, São Paulo, Ed. LTR, p. 133-142
} 
essencial, já que estará garantido o direito de ação, mas apenas uma opção da sociedade e dos associados pela utilização da jurisdição arbitral e não da jurisdição estatal." (Vilela, Marcelo Dias Gonçalves, Arbitragem no Direito Societário, Ed. Mandamentos, Belo Horizonte)

Não parece ser este o melhor raciocínio, pois a discussão sobre os direitos essenciais não gravita apenas em torno do denominado "direito de ação" e da "ampla defesa", mas também em torno do próprio acesso à justiça. Imagine-se a hipótese de companhia que decida por resolver seus conflitos na Câmara de Comércio Internacional em Londres - CCI. Teria um acionista minoritário ou de inferior condição financeira, plenas de litigar em iguais condições perante os controladores? E mais, e quando a um remoto acionista que adquiriu seus ações no mercado aberto?

Não há dúvidas que a clausula compromissória é estipulada em benefício da sociedade e perante ela, pessoa jurídica, produzirá efeitos. Já quanto aos sócios, na esfera de seus direitos individuais que advém da sua condição de sócio, a clausula compromissória terá seus efeitos condicionados a manifestação da vontade em aderir ao pacto arbitral.

Isso sem se mencionar a parte final do disposto no Art. 111 do Código Civil, abaixo transcrito, merece atenção diferente àquela data pela autora supra mencionada:

"O silêncio importa anuência, quando as circunstâncias ou os usos o autorizarem, e se não for necessária a declaracão expressa de vontade.

Parece evidente que a intenção do legislador ao estabelecer logo no art. $1^{\circ}$ da Lei de Arbitragem, que "As (sic) pessoas capazes de contratar poderão valer-se da arbitragem para dirimir litígios relativos a direitos patrimoniais disponíveis”, era atribuir expressa manifestação da parte 
contratante, manifestação essa que pode ocorrer em quaisquer das formas conhecidas no direito. Mas tem que haver, e não pode ser, sequer, duvidosa.

Repita-se para enfatizar, a natureza objeto da clausula arbitral é uma renúncia a direito essencial do indivíduo, garantido no plano constitucional.

\subsection{1 - Das Clausulas Compromissórias "cheias" e "vazias"}

Desviando-se do foco em discussão, cumpre um breve parêntese a respeito das modalidades de clausulas compromissórias definidas na Doutrina.

A primeira, denominada "clausula vazia", é aquela determina a instauração do juízo arbitral para composição de conflitos. Ex.: " $A s$ divergências que poderão surgir entre as partes, assim entendidas sociedade, acionistas majoritários e minoritários, serão dirimidas pela via arbitral.”

Nota-se que não há: (i) definição do tribunal arbitral a ser utilizado; (ii) a forma de nomeação dos árbitros; (iii) a indicação da legislação a ser aplicada, e, finalmente, (iv) a delimitação dos conflitos que serão levados a jurisdição arbitral. Quando presentes todos os elementos expostos, dar-se-á a denominação de "cláusula cheia". Sugere-se a seguinte redação:

"As divergências que poderão surgir entre as partes, assim entendidas a sociedade e seus acionistas e ou entre acionistas controladores e minoritários em relação a interesses legais e estatutariamente reconhecidos, e as divergências de interpretação, aplicação e exercício dos direitos e obrigações decorrentes da atividade social ou da situação de acionistas, serão dirimidos pela Câmara de Arbitragem $X$, devendo os árbitros serem nomeados na forma $Y$, seguindo as regras e os regulamentos arbitrais dessa mesma sociedade, e nos estritos termos da Lei $n^{\circ}$ 9.307/96" 
A utilização deste último modelo é recomendada amplamente na doutrina, pois é considerada capaz de restringir ao máximo a discussão sobre a própria validade da clausula. Como exemplo, segue o modelo proposto por Modesto Carvalhosa ${ }^{29}$ para os contratos de sociedade:

"Essa clausula cheia facilita imensamente a posterior instituição do compromisso arbitral, na medida que não será necessário apontar árbitros no momento da controvérsia ou da lide. Do contrário, a discussão sobre os nomes e o número de árbitros no caso tornará difícil a celebração do sucessivo compromisso, frustrando, por conseguinte, os objetivos da adoção do juízo arbitral"

Toda preocupação com texto da clausula tem razão quando observado o árduo caminho pelo qual esta passou até ser reconhecida sua validade e eficácia. Na França, em importante decisão, mencionada anteriormente, proferida por sua Corte de Cassação - $1843^{30}$, baniu-se a clausula compromissoria, declarando-se suas nulidades pelos seguintes fundamentos destacados por Jean Robert.

"le motif juridique de cette nullité etait le defáut de détermination de litige e (sic) et de désignation des arbitres dans la clause compromissoire"

Essa decisão foi proferida em uma lide proposta por uma companhia de seguros que, fundada na clausula compromissória prevista em sua apólice, buscava a instauração de um tribunal arbitral em Paris. Sob a alegação de que não era possível determinar o objeto do litígio, muito menos nomear os árbitros na clausula compromissória, foi negada eficácia à clausula servindo como leading case por quase um século, para invalidar outras clausulas dessa natureza na França, que ingressou novamente no

\footnotetext{
${ }^{29}$ CARVAlhosA, Modesto. A Clausula Compromissoria Estatutária p 322-343, in A Reforma da Lei das Sociedades Anônimas. Coordenador Jorge Lobo, Ed. Forense, São Paulo.

${ }^{30}$ Chambre Civile du 10 de juillet 1843 - 1843.561.
} 
ordenamento jurídico apenas após a edição do protocolo de genebra de $1923^{31}$. Seguem alguns trechos da decisão ${ }^{32}$ :

\section{(...)}

- Que la distinction entre une convention compromissoire et un compromis, n'est établie par aucune disposition de loi, et qu'on ne pourrait l'admettre sans méconnaitre le véritable esprit du Code de procédure au titre des arbitrages; - Qu'on invoque inutilement, pour valider dans les matières civiles la clause dite compromissoire, l'art. 1134, Code civ., puisque les conventions ne tiennent lieu de loi à ceux qui les ont faites que lorsqu'elles sont légalement formées, et qu'une convention n'est pas légale quand elle est dépourvue des conditions expressément exigées par le législateur; (...)

"Attendu qu'il suit de ce qui précède qu'en déclarant nulle la convention d'arbitrage de la police du 28 septembre 1837, pour défaut de désignation du nom des arbitres, non seulement l'arrêt attaqué n'a violé aucune loi, mais qu'il a fait une juste interprétation de l'art. 1134, Code civ., et une juste application des art. 1003 et 1006, Cod. proc.; - Sans qu'il soit besoin d'examiner si l'objet du litige avait été suffisamment indiqué; - Rejette"

No Brasil, interpretação semelhante foi dada pelo Min. Sepúlveda Pertence, quando entendeu pela inconstitucionalidade dos Art. $6 \S$ único e Art. $7^{\mathrm{o}}$ da Lei 9.307/96, no julgamento do SE AgR. 5.206- $\mathrm{STF}^{33}$, sendo contrariado pelo mestre Celso Barbi Filho ao dizer que "se não é determinado ao tempo da clausula arbitral é pelo menos determinável, dentro dos limites do contrato. " 34

Esse pensamento, parece estar de acordo com o Art. 104 do código civil supra-transcrito, bem como com Art. 121 da mesma lei.

\footnotetext{
31 VILELA, Marcelo Dias Gonçalves. Arbitragem no Direito Societário. Belo Horizonte. Mandamentos: p. 79

${ }^{32}$ Cour de Cassation (Chambre Civile) - 10 Juillet 1843.

33 VILELA, Marcelo Dias Gonçalves. Arbitragem no Direito Societário. Belo Horizonte. Mandamentos: p. 81

${ }^{34}$ BARBI, Celso Filho. Cumprimento judicial de clausula compromissoria na Lei 93.07/96 e outras intervenções do judiciário na arbitragem privada. Rio de Janeiro: Revista de Direito Mercantil, 1997. p. 89
} 
"Lei 10.402/02, Art. 121. "considera-se condição a cláusula que, derivando exclusivamente da vontade das partes, subordina o efeito do negócio jurídico a evento futuro e incerto."

Apesar de toda a dificuldade de reconhecimento da clausula compromissória ao longo do tempo, não vê-se razão para tanto, seja pelos fundamentos acima expostos, seja pela própria previsão legal de sua validade da Lei de Arbitragem.

Conforme se depreende das explanações transcritas, a clausula compromissória estatutária possui particularidades, devido ao seu instrumento de inserção e as relações envolvidas. Dessa forma, necessário se faz particularizar os contornos envolvidos, para que se tenha ainda mais clara a posição defendida, razão pela qual passa-se ao estudo do contrato de sociedade.

\subsection{Contrato de Sociedade e as relações sociais}

O estudo da natureza jurídica do contrato de sociedade se constituiu como um dos pontos do qual se ocupou por longo período a doutrina do direito comercial, seja para delimitar o objeto contratual, seja definir a predominância de interesses da pessoa do sócio ou mesmo da própria pessoa jurídica.

$\mathrm{Na}$ doutrina brasileira, a natureza contratual do estatuto social encontrou sua melhor definição nas palavras de Bulhões Pedreira que ensinam:

"Não se conhece até hoje a formulação de regime jurídico, a partir da análise sociológica, econômica e política das grandes empresas, que substitua a conceituação da companhia como contrato" 
Nesse sentido, complementa Túlio Ascarelli ${ }^{35}$ ao defini-lo como contrato plurilateral, em que as partes convergem seus esforços para um fim comum. Dessa forma, os contratos de sociedade, principalmente nas sociedades de capital, desvinculam-se das figuras das partes, criando um novo sujeito de direito.

Assim é, pois os contratos plurilaterais associativos não se resolvem, por exemplo, pelo descumprimento de obrigações daqueles que o convencionaram, na medida em que dele resulta uma nova pessoa jurídica de que destaca de seus sócios. Nem mesmo pela mudança das partes com ingresso ou saída de integrantes.

Quando da saída de sócios, a sociedade, como pessoa de direito, poderá adquirir a participação societária dissidente, depositando-as em tesouraria ou simplesmente operando uma redução de capital.

Com efeito, percebe-se desde logo a pluralidade de relações existente nas sociedades, umas travadas entre a sociedade e os sócios e outras entre esses.

Essa distinção ganha importância quando se passa a aceitar a validade da clausula compromissória no contrato da sociedade, com base nos conceitos de unicidade da assembléia e do interesse social inserida por meio de alteração contratual.

\subsection{1. - Da unicidade da Assembléia}

Conforme mencionado, a constituição de uma sociedade gera o nascimento de um novo sujeito de direitos, desprendido dos interesses particulares de cada sócio.

35 ASCARELLI, Túlio. Problemas das sociedades anônimas e direito comparado. São Paulo, 
Daí surge o denominado princípio do interesse comum da sociedade que consiste em todo ato praticado pela companhia, sócios ou assembléia que esteja em linha com o objeto e a finalidade desta. É mister que a sociedade e seus sócios tem como objetivo a constituição de lucro, dessa forma todo ato praticado com este objetivo, será recebido como interesse comum.

Os sócios como partes da sociedade terão na Assembléia Geral o meio para expressarem suas vontades. Sendo esta composta por todos aqueles que possuem direito a voto, ressalvadas as hipóteses especiais previstas em lei para participação daqueles cujo título não permita, precipuamente, o exercício desse direito político, tomar-se-ão as decisões sob a regra da maioria.

Há quem aponte a regra da maioria como uma necessidade fisiológica inerente a disciplina das sociedades por ações. Afirma Carvalho de Mendonça ${ }^{36}$ que :

"Exigir a unanimidade seria expor a sociedade por ações à inação, seria cair no absurdo de atribuir a um só acionista a qualidade de representante ou árbitro da vontade social."

Tais considerações contribuem para ilustrar que válida e eficaz é a disposição arbitral no estatuto da sociedade quanto a sociedade em si quando regularmente aprovada em assembléia. Mas limitada estará sua eficácia quando esta envolver um interesse particular de um determinado acionista, em meio a pluralidade das relações societárias. 
Pode-se dizer que frente aos acionistas que não aderiram expressamente a clausula arbitral, não votaram em assembléia ou nela não se fizeram presente, esta terá seus efeitos suspensos, constituindo-se em verdadeira exceção ao princípio da unicidade da assembléia e do estatuto social, pois vinculada a essa deliberação estará o interesse comum da sociedade, até o limite constitucional particular de um acionista.

Remete-se portanto, a explanação anteriormente exposta sobre a plena validade e eficácia da clausula frente à sociedade e sua restrição a necessidade de expressa manifestação de vontade do sócio.

\subsection{2 - Contratos de Adesão e Contratos de Sociedade}

Necessário também é contrapor os contratos de sociedade aos contratos de massa, conhecidos como "contratos de adesão". Isso, porque a Lei 9.307/96 cria regra específica para instauração do juízo arbitral nessas relações:

"Art. 4, $\$ 2^{\circ}$ - " $\$ 2^{\circ}$ Nos contratos de adesão, a cláusula compromissória só terá eficácia se o aderente tomar a iniciativa de instituir a arbitragem ou concordar, expressamente, com a sua instituição, desde que por escrito em documento anexo ou em negrito, com a assinatura ou visto especialmente para essa cláusula.

Sustenta-se que essa regra seria aplicável às sociedade, em especial no tocante à admissão de novos sócios. Nas palavras de Alessandro Nigro ${ }^{37}$, " $o$ novo acionista tem diante de si um contrato de conteúdo já determinado por outros no qual deve ele limitar-se a aderir, sem possibilidade de promover alteração alguma".

\footnotetext{
${ }^{37}$ CARVAlHOSA, Modesto. Clausula Compromissória Estatutária. In Logo, Jorge (org.)
} Reforma da Lei das Sociedades Anônimas. $2^{\mathrm{a}}$ Ed. Rio de Janeiro: Forense., 2000. p; 326 (apud) 
Modesto Carvalhosa em seu artigo sobre a clausula compromissória estatutária, publicada na obra "A Reforma da Lei das Sociedades Anônimas", coordenado pelo Prof. Jorge Lobo, vale-se das palavras do mesmo jurista italiano para embasar sua tese de expressa anuência ao pacto arbitral:

“a exigência de prévio conhecimento e a consciente aceitação do aderente a respeito da pactuação que a lei presume merecedora de especial atenção, garante e cria a relação entre a vontade do sujeito que adere e o conteúdo da clausula cuja formação não participou. Portanto, a clausula compromissoria inserida no ato constitutivo ou no estatuto da sociedade deve ser especificamente por escrito pelos sócios que nela posteriormente ingressam e, assim, juntam-se ou substituem acionistas anteriores, sob pena de sua invalidade" (NIGRO, Alessandro. - Questioni vecchie e nuove in materia di clausula compromissoria negli statuti di società, in Rivista delle Società, fasc. 11968, p. 192)

Em que pese a concordância a boa parte da posição defendida pelo ilustre jurista brasileiro, não parece ser esse o ponto fundamental para necessidade de expressa anuência a clausula que elege o foro arbitral como competente para mediação de controvérsias oriundas destas relações.

Se assim fosse, a simples equiparação do contrato de sociedade aos contratos de adesão, resolveria a questão posta, sem a necessidade de adentrar-se nas matérias dos direitos essenciais e da autonomia da vontade.

O que se percebe é que em determinadas características, ambos contratos terão pontos de tangência como aquelas referentes a ausência da condição de negociabilidade das condições pré-existentes, a imutabilidade destas, condicionadas a concordância da maioria dos demais acionistas.

NIGRO, Alessandro. Questioni vecchie e nuove in materia di clausula compromissoria negli statuti di società, in Rivista delle Società, fasc. 1 genn.-febb. 1968. 
Porém, a leitura do dispositivo legal do $\S 2^{\circ}$ do Art. $4^{\circ}$ da Lei 9.307/96, leva a inequívoca conclusão que a intenção do legislador ao criar tal regra, era proteger partes hipossuficientes de clausulas compromissórias inseridas em contratos de massa, como os bancários ou de prestação de serviços de comunicação, transportes entre outros.

Nas relações societárias a condição de hipossuficiência não é regra, não devendo a lei ser aplicada em sentido amplo. Maior incidência será encontrada nas sociedades com capital negociado em bolsa, onde é comum encontrar investidores comuns em condições de hipossuficiência em relação aos demais acionistas da sociedade. Mesmo assim é cediço que o mercado mobiliário brasileiro é pouco democrático, restrito a uma pequena parcela social de investidores.

Com efeito, o caráter definitivo ao tema se dará no estudo caso a caso dentro do Poder Judiciário, quando provocado. A lei, apesar de buscar proteger o indivíduo e coibir abusos de direitos, quando criada com propósitos específicos, o é para situações de larga incidência, obedecendo ao princípio do estado democrático de direito.

\section{3 - Da Relação Jurídica entre a Clausula Compromissória e o Estatuto Social.}

Expostas as argumentações a respeito da clausula compromissória em si e seu veículo nas relações entre sócios e sociedade, passa-se a analise da relação travada diretamente entre estes. Fundamental será demonstrar a independência que rege essa relação, culminando em observação fundamental para pulverizar quaisquer dúvidas sobre a necessidade de expressa anuência a instauração do juízo arbitral que ainda suportassem as fundamentações tecidas. 
Inicialmente se demonstrará a independência das clausulas compromissórias aos contratos que se encontram inseridas, defendida por parte da doutrina como fundamento a isentar de nulidade a clausula quando presente em contratos contaminados por vícios. Inclusive há quem defenda que este pacto deve vir em documento apartado ou que o contrato deverá prescindir de duas manifestações de concordância, uma ao objeto contratado e outra a própria clausula arbitral.

Posteriormente se passará a análise da classificação da clausula compromissoria dentro do contrato de sociedade, necessária a visualização da incidência desta sobre todas as partes envolvidas na relação.

\subsection{1 - Autonomia da clausula compromissoria}

Se a lei de arbitragem em seu art. $8^{\mathbf{0} 38}$ já não bastasse para regular definitivamente, encontra-se na doutrina feroz defesa da autonomia da clausula arbitral, como a se tira de Pierre Yves Tschanz ${ }^{39}$ ao afirmar que "la convention d'arbitrage est une convention à part entière dont l'objet propre este règlement de certains lities", concluído que "C'est pourquoi, même lorsqu'elle est insérée dans une clause du contrat principal, la convención d'arbitrage conserve une nature autonome (...)’”.

Por isso que válida é a instauração de um juízo arbitral, mesmo quando presente no contrato ao qual a convenção esta inserida, vícios que o tornem nulo ou anulável. Esse juízo terá, inclusive, a obrigatoriedade de apreciar sobre competência para julgar a causa, conforme determina o art. 20 da Lei Arbitral ${ }^{40}$.

\footnotetext{
${ }^{38}$ Art. $8^{\circ}$ A cláusula compromissória é autônoma em relação ao contrato em que estiver inserta, de tal sorte que a nulidade deste não implica, necessariamente, a nulidade da cláusula compromissória 39 VILELA, Marcelo Dias Gonçalves. Arbitragem no Direito Societário. Belo Horizonte. Mandamentos (apud) TSCHANZ, Pierre Yves. La convention d'arbitrage. Revue de Droit des Affaires Internationales, ${ }^{\circ}$ 6, 1989. p. 750.

${ }^{40}$ Art. 20. A parte que pretender argüir questões relativas à competência, suspeição ou impedimento do árbitro ou dos árbitros, bem como nulidade, invalidade ou ineficácia da
} 
$\mathrm{Na}$ hipótese de suscitados vícios que acarretem a nulidade do contrato de sociedade, o juízo arbitral instaurado deverá apreciar e julgar a matéria. Isso explicita a natureza autônoma da clausula arbitral ${ }^{41}$, uma vez que se reconhece um direito próprio, emerge de tal avença em relação ao contrato em que esta de adere.

Da mesma que forma que a clausula compromissória encontra autonomia a vícios do contrato vinculado, esta deverá conter expressa anuência, independente daquela posta em acordo ao contrato assinado. Sem falar então quando esta vier em documento apartado.

Nesse sentido, não é demais repetir-se a natureza fundamental do pacto arbitral, qual seja, renúncia ao direito essencial da prestação jurisdicional do estado. Além do mais a clausula não possui relação direita, senão instrumental ao contrato.

Para Carlos Alberto Carmona ${ }^{42}$ :

"As partes, ao encartarem em determinado contrato uma cláusula arbitral, inserem nele uma relação jurídica diferente, manifestando vontade apenas no que se refere à solução de eventuais litígios pela via arbitral ${ }^{43}$; esta vontade, portanto, não tem ligação (senão instrumental) com o objeto principal do negócio jurídico (uma compra e venda, uma associação, um contrato de prestação de serviços) (...)" (grifos aditados)

convenção de arbitragem, deverá fazê-lo na primeira oportunidade que tiver de se manifestar, após a instituição da arbitragem.

41 VILELA, Marcelo Dias Gonçalves. Arbitragem no Direito Societário. Belo Horizonte. Mandamentos: p. 110.

42 VILELA, Marcelo Dias Gonçalves. Arbitragem no Direito Societário. Belo Horizonte. Mandamentos: p. 111. (apud) CARMONA, Carlos Alberto. Arbitragem e processo: um comentário à Lei 9.307/96. São Paulo, Ed. Malheiros, 1998, p. 119.

${ }^{43}$ Condição nos termos do Art. 121 do Código Civil. 
No que tange a possível alegação de nulidade da própria clausula arbitral, poderá esta ser objeto da ação prevista no Art. 32, I ou IV da Lei 9.307/96 4 . Ao Poder Judiciário caberá, se provocado dentro do prazo decadencial de noventa dias, exercer o controle acerca da nulidade suscitada, preliminarmente examinando a própria competência do juízo arbitral.

Não poderá o poder judiciário impedido de pronunciar-se acerca da incompetência, ausência de investidura ou imparcialidade dos árbitros, antes que estes previamente analisem tais questões suscitadas. O Judiciário agirá, nessa hipótese, em sua função controladora ${ }^{45}$.

\subsection{2 - Da natureza parassocial da clausula compromissória estatutária}

Forçoso é analisar inicialmente o texto da Lei das Sociedades Anônimas com advento da Lei 10.303/02 que alterou seu art. 109 que assim passou a dispor:

"Art. 109: Nem o estatuto social nem a assembléia geral poderão privar o acionista de:

$\$ 3^{\circ}$ - O estatuto da sociedade pode estabelecer que as divergências entre os acionistas e a companhia, ou entre acionistas controladores e os acionistas minoritários, poderão ser solucionadas mediante arbitragem, nos termos em que especificar. (grifos aditados)

Da própria letra da lei, passível é a interpretação de que o estatuto social como instrumento de obrigações entre os acionistas é independente da clausula compromissória. Destaca-se: "os conflitos poderão" e não

\footnotetext{
${ }^{44}$ Art. 32: É nula a sentença arbitral se:

I - for nulo o compromisso

IV - se for proferida fora dos limites da convenção de arbitragem

${ }^{45}$ VILELA, Marcelo Dias Gonçalves. Arbitragem no Direito Societário. Belo Horizonte. Mandamentos: p. 113.
} 
“deverão", logo, a previsão convenção arbitral é uma faculdade da companhia e uma opção dos sócios, que será definida, no plano da sociedade, pela regra da maioria, e dos sócios que manifestaram individualmente sua vontade, seja pelo voto positivo em assembléia, seja por posterior adesão a clausula.

Máxima vênia, discorda-se mais uma vez da posição defendida por Denise Barbosa Moreira ${ }^{46}$ que chega a afirmar: "tal interpretação literal da norma conduziria à sua inutilidade. Seria, ademais, incompatível com a execução especifica da clausula compromissória (...)”,

A mesma autora ainda conclui que:

“(...)Com isso, lemos a expressão "poderão ser solucionadas mediante arbitragem" como "deverão ser solucionadas mediante arbitragem", ou simplesmente, "serão solucionadas mediante arbitragem".

Olvida-se a ilustre autora de renomado sobrenome, que a clausula arbitral não será oposta orga omnes à todos os acionistas da sociedade, sendo o mais correto afirmar que: "serão solucionados mediante arbitragem, respeitados os limites da adesão das partes"

Em se tratando de uma faculdade, evidenciado fica que a clausula não se confunde com os interesses gerais da companhia, expressados através das clausulas organizativas, constituindo-se em inegável "clausula

\section{parassocial'"}

Tem-se por clausulas organizativas aquelas que versam sobre o objeto na sociedade, forma de instauração e deliberação da assembléia

\footnotetext{
${ }^{46}$ MOREIRA, Daniela Bessone Barbosa. A convenção arbitral em estatutos e contratos sociais. (org.) in ALAMEIDA, Ricardo Ramalho "Arbitragem Internacional - questões de doutrina e da prática”, coordenado por. Ed. Renovar, Rio de Janeiro. P. 363-391
} 
geral, eleição dos cargos executivos e de administração, entre outras. São as quais a companhia é guiada, muitas delas presentes no contrato da sociedade em virtude de lei.

$\mathrm{Na}$ clausula arbitral a sociedade não figura como centro interesses, mas sim como parte no pacto. No mesmo sentido, Carvalhosa ${ }^{47}$ afirma que esta "despe-se, por conseguinte do seu poder de impor a todos s acionistas a clausula compromissória estatutária na medida em que se coloca como parte (...)."

Com efeito, a clausula não adquire caráter associativo não sendo por isso vinculativa a todos as partes do contrato de sociedade.

Trata-se a clausula arbitral de uma convenção entre a companhia e determinados sócios que manifestaram individualmente sua vontade. Cuidase portanto, de um pacto parassocial entre a sociedade e estes acionistas, assim como os acordos de acionistas previstos no Art. 118 da Lei $6404 / 76^{48}$

Valendo-se novamente das palavras do ilustre comercialista ao mencionar dois respeitáveis juristas italianos: “49 Há, como lembra: ${ }^{50}$ Oppo em apoio a Vivante: "clara distinção entre a livre manifestação de vontade dos acionistas e a obrigação destes como membros da sociedade”.

\footnotetext{
${ }^{47}$ CARVAlHOSA, Modesto. Comentários à Lei de Sociedades Anônimas V. 2. Rio de Janeiro: Saraiva, 2003. p. 310.

${ }^{48}$ Lei 6404/76. Art. 118 - Os acordos de acionistas, sobre a compra e venda de suas ações, preferência para adquiri-las, exercício do direito a voto, ou do poder de controle deverão ser observados pela companhia quando arquivados na sua sede

${ }^{49}$ CARVALHOSA, Modesto. Comentários à Lei de Sociedades Anônimas V. 2. Rio de Janeiro: Saraiva, 2003. p. 312

${ }^{50}$ CARVALHOSA, Modesto. Comentários à Lei de Sociedades Anônimas V. 2. Rio de Janeiro: Saraiva, 2003. p. 310. (apud) Oppo, Giorgio. I contratti parassociali, Milano, Ed. Valiardi 1942 p. 3 e ss.
} 
Isto posto, não pode haver presunção de renúncia a direito essencial de qualquer acionista, como os previstos no Art. 109 da Lei das Sociedades Anônimas, tanto mais em se tratando de pacto parassocial. Repita-se para enfatizar que "a renúncia deverá ser interpretada restritivamente" não sendo presumível que um indivíduo atribuiria a um juízo arbitral a solução de quaisquer controvérsias, pelo simples fato desta previsão estar disposta no estatuto da sociedade.

Por derradeiro, destaca-se o dispositivo que inseriu a Arbitragem no ordenamento das sociedades anônimas, $\S 3^{\circ}$ do Art. 109 da Lei das S.A., sendo posterior ao $\$ 2^{\circ}$ do Art. $109^{51}$ da mencionada Lei, deve ser lido em consonância com este.

Logo, se nem o estatuto, nem a assembléia podem elidir os meios, processos ou ações que a lei confere em defesa do acionista, apenas o próprio será capaz de fazê-lo, de modo que a manifestação expressa e inequívoca que o direito a provocação da jurisdição estatal não poderá ser afastado.

\section{IV - Dos efeitos em relação as partes no contrato de sociedade}

Expostas as considerações sobre o tema e demonstrada a natureza personalíssima do pacto arbitral, válido será pontuar os efeitos em relação aos sócios quanto ao momento da inserção da clausula compromissória no contrato de sociedade e o tipo societário da sociedade.

A abordagem sobre o chamado direito de recesso também se faz necessária, haja vista ser esta a opção legal prevista aos acionistas que

\footnotetext{
${ }^{51}$ Lei $6404 / 76$ - Art. $109 \S 2^{\circ}$ Os meios, processos ou ações que a lei confere ao acionista para assegurar os seus direitos não podem ser elididos pelo estatuto ou pela assembléia-geral.
} 
passem a discordar dos rumos da sociedade dados em assembléia, caminho defendido por exemplo por Pedro A. Batista Martins, em claro posicionamento em favor de acionistas majoritários.

\subsection{Do Instrumento de Constituição da Sociedade}

Grande parte argumentos apresentados nos capítulos anteriores seguiam a premissa dos efeitos em relação aos sócios da clausula compromissoria inserida por meio de alteração contratual aprovada por decisão da maioria do capital votante da sociedade.

Nessas hipóteses o contrato da sociedade terá o caráter dictatus ${ }^{52}$ na definição de Carvalhosa, fundamental na distinção dos efeitos da clausula compromissoria quando o momento de sua inserção do contrato. Diz o Ilmo. comercialista:

"O caráter de dictatus do estatuto social somente dá-se no caso de aquisição de ações posteriormente aos atos constitutivos. Ressalta-se esse ponto."

O contrato da sociedade estará ditando as regras ao acionista que adere, diferentemente do acionista que faz-se presente no ato da constituição da sociedade. Na constituição da sociedade as partes estão aprovando o contrato da sociedade, tendo este caráter tratatus, vinculando a clausula compromissoria a todos os acionistas presentes no ato:

"Assim, no momento da constituição da sociedade estarão vinculados à clausula compromissória todos os fundadores que subscreveram o capital social.

$\underline{\text { São eles que fundam a sociedade e aprovam seu }}$ estatuto. Pode-se dizer, portanto, que os fundadores subscritores não aderem, mas efetivamente o aprovam. Fique bem clara a distinção. No caso, os atos constitutivos e, dentre eles, a aprovação do estatuto são

52 CARVAlHOSA, Modesto. Clausula Compromissória Estatutária. In Logo, Jorge (org.) Reforma da Lei das Sociedades Anônimas. ${ }^{a}$ Ed. Rio de Janeiro: Forense., 2000. 
tratatus entre os fundadores e não dictatus" ${ }^{53}$ (grifos aditados)

Parece ser este, o ato constitutivo, o único ponto de coincidência entre os dois juristas que melhor trataram a matéria até a presente, conforme trecho publicado por Pedro A. Batista Martins abaixo transcrito ${ }^{54}$ :

"Os atos constitutivos, certamente, e suas posteriores alterações, normalmente, refletem a manifestação individual dos quotistas dada a expressa confirmação pela aposição da assinatura no instrumento correspondente."

Onde se lê "quotistas", o mesmo autor, observa que o raciocínio também é aplicável ${ }^{55}$ :

"Parece-me, por sinal, que o mesmo raciocínio e reflexões formuladas às Limitadas, se aplicam, em regra geral as Anônimas."

De fato, sendo o ato constitutivo o único em que se pode garantir a concordância de todas as partes na relação societária, resultando o estatuto da convergência da vontade de todos presentes, a inserção da clausula compromissoria mostra-se como exteriorização da vontade individual de cada um. Negar-lhe aplicabilidade a um determinado acionista, seria adentrar-se na esfera do venire contra actum proprium vedado no ordenamento jurídico nacional.

Quanto as alterações contratuais nas sociedades limitadas, vias de regra, são arquivadas no Registro do Comércio, sem o extrato de votação, e assinada por todos os sócios. Nesses casos, merece especial atenção do

53 CARVAlHOSA, Modesto. Clausula Compromissória Estatutária. In Logo, Jorge (org.) Reforma da Lei das Sociedades Anônimas. $2^{\mathrm{a}}$ Ed. Rio de Janeiro: Forense., 2000.

${ }^{54}$ MARTINS, Pedro A. Batista. A arbitragem nas sociedades de responsabilidade limitada in. Reflexões sobre arbitragem: in memoriam do Desembargador Cláudio Vianna de Lima, in. São Paulo, Ed. LTR, p. 133-142 
quotista que não deseje vincular-se a clausula compromissoria inserida nessa alteração, pois constando da alteração sua assinatura e nada mencionando sobre sua discordância, difícil ficará provar, posteriormente sua posição dissidente.

\subsection{Das demais hipóteses}

Entenda-se como "demais hipóteses" as seguintes: (i) acionista que ingressa em sociedade, cujo arbitragem é o meio adotado pelo contrato para solução de conflitos, seja pela compra de ações pré-existentes, seja pela emissão de novas; (ii) deliberação social que insere a clausula compromissoria no contrato aos acionistas silentes, ausentes ou dissidentes da assembléia; (iii) acionista que adquire ações por sucessão, quando o titular anterior aderira a clausula compromissória.

Apesar das evidentes distinções das hipóteses acima, a fundamentação para necessidade da expressa anuência a clausula arbitral adotadas na doutrina serão as mesmas as já expostas.

A corrente que segue o pensamento de Pedro A. Batista Martins defende estar o instituto da arbitragem em perfeita sintonia com Art. 50, XXXV da CF. 1988, não havendo o que se falar em matéria de renúncia a direito essencial, afastando portanto a idéia de pacto personalíssimo.

O referido autor chega a afirmar que ${ }^{56}$ "na arbitragem, as regras e a solução da pendência são concluídas em caráter privado, contudo sob o manto do próprio Estado, legislador primário do instituto."

\footnotetext{
${ }^{55}$ MARTINS, Pedro A. Batista. A arbitragem nas sociedades de responsabilidade limitada in. Reflexões sobre arbitragem: in memoriam do Desembargador Cláudio Vianna de Lima, in. São Paulo, Ed. LTR, p. 133-142
} 
Em consonância com esse pensamento, o prof. mineiro Marcelo Dias Gonçalves Vilela afirma que "a clausula compromissória não se trata de renúncia a direito essencial, já que estará garantido o direito de ação, mas apenas uma opção da sociedade e dos associados pela jurisdição arbitral e não da jurisdição estatal."

Sobre espécie em que se configura a clausula arbitral no contrato da sociedade, o mesmo autor se opõe a Carvalhosa afirmando que ${ }^{58}$ :

“A convenção arbitral (clausula compromissória) integra-se ao próprio estatuto ou contrato social e independentiza-se da vontade dos sócios fundadores ou instituidores para se tornar uma "vontade" (norma) social, que vincula as relações entre todos os associados. $\mathrm{Na}$ verdade, a clausula compromissoria societária não é uma regra para-estatutária (parassocial), mas coloca se como regra orgânica da sociedade"

Sob esse enfoque, a clausula compromissória produzira efeitos a todos os associados que se integrem como parte da sociedade, independentemente da forma de aquisição da quota ou ação. Seria oposta erga omnes traduzindo-se, em outras palavras, em uma condição da sociedade.

Não parece ser este o melhor raciocínio conforme se pode perceber das argumentações defendidas nos capítulos anteriores. Não é aceitável que a adoção do juízo arbitral como mera opção pelo juízo privado em detrimento do estatal. A previsão de prestação jurisdicional pelo estado faz parte das garantias essenciais do indivíduo e deve ser tratada de forma prudente e diferenciada, pois essa foi a intenção do legislador constituindo ao incluir esta previsão no importante Art. $5^{\circ}$ da CR/88.

\footnotetext{
${ }^{56}$ MARTINS, Pedro A. Batista. Arbitragem e o Art. $5^{\circ}$, XXXV da Constituição da República de 1988. Revista de Direito Civil, Imobiliário, Agrário e Empresarial, Rio de Janeiro, v. 77, p. 177188.

57 VILELA, Marcelo Dias Gonçalves. Arbitragem no Direito Societário. Belo Horizonte. Mandamentos: p. 256.

58 VILELA, Marcelo Dias Gonçalves. Arbitragem no Direito Societário. Belo Horizonte. Mandamentos: p. 285
} 
A adoção do juízo arbitral não significa uma simples opção pela jurisdição privada, mas sim uma negação a prestação jurisdicional ordinária.

Além do mais, as garantias e recursos previstos a defesa da parte na jurisdição estatal são infinitamente mais abrangentes, a opção pelo juízo privado significa abrir mão destas. $\mathrm{O}$ que se falar dos limites a propositura de ação rescisória contra laudo arbitral? Estaria este limitado ao disposto no Art. 32 9.307/96 ou se poderiam aplicar as regras do código de processo civil?

Há uma série de direitos que são afastados ao ingressar-se no juízo arbitral. Dessa forma, evidente que sua causa de adesão deve merecer especial cuidado, pelo que adota-se a posição cautelosa defendida pelo eminente jurista Modesto Carvalhosa, por todos argumentos até aqui expostos nesse sentido.

Cumpre ressaltar que esse posicionamento não se confunde com a legalidade do instituto, perfeitamente válido, legal e necessário ao desenvolvimento do ordenamento jurídico nacional e o fortalecimento, inclusive, do mercado mobiliário que ganha reforço em termos de segurança e tecnicidade das decisões, elementos que contribuirão na atração de investidores.

Limitam-se estes apenas quanto a necessidade de concordância expressa e inequívoca da parte para estar vinculada.

Esse entendimento é também adotado pelo seguimento do Novo Mercado da Bovespa, conforme de depreende do Regulamento da Câmara de Arbitragem do Mercado: 
"2. - C CARACTER OBRIGATÓRIO DO

REGULAMENTO

2.1 - O Regulamento obriga indistintamente os seguintes participantes dos Segmentos Especiais de Listagem da BOVESPA

vi) os investidores, desde que tenham, voluntariamente, anuído ao Regulamento por meio da assinatura do Termo de Anuência, nos termos do item 5.2.2 do Presente Regulamento" (grifos aditados)

Para reforçar esse entendimento, é válido mencionar o posicionamento da Corte de Cassação Civil Italiana, publicada em Giurisprudenzia Italiana n. ${ }^{0} 781$, coletada por Modesto Carvalhosa ${ }^{59}$, que decidiu pela necessidade de manifestação por escrito das partes para que possam validamente comprometer-se à solução arbitral dos conflitos decorrentes do contrato objeto do litígio, em razão da derrogação da competência da autoridade judiciária ordinária que constitui garantia constitucional também naquele país.

Também na Itália, foi editado decreto lei em sentido oposto a supra citada decisão:

"Decreto Legislativo 17 janeiro 2003, $\mathrm{n}^{\circ} .5$ - Art. 34.2 - 'La clausola é vincolante per la societá e per tutti i soci, inclusi coloro la cui qualitá di socio é oggetto della controversia."

Há de se esperar os efeitos práticos dessa norma, bem como qual interpretação será dada pela Corte de Cassação Italiana.

A lei nacional prevê o direito de recesso ao acionista dissidente. Nas palavras de Pedro Batista Martins ${ }^{60}$, "ao sócio dissidente resta o direito de

59 CARVAlHOSA, Modesto. Clausula Compromissória Estatutária. In Logo, Jorge (org.) Reforma da Lei das Sociedades Anônimas. ${ }^{\mathrm{a}}$ Ed. Rio de Janeiro: Forense., 2000. p. 342, nota 5. MARTINS, Pedro A. Batista. A arbitragem nas sociedades de responsabilidade limitada in. Reflexões sobre arbitragem: in memoriam do Desembargador Cláudio Vianna de Lima, in. São Paulo, Ed. LTR, p. 133-142 
se retirar da sociedade a qualquer tempo por mora discordância de deliberação social."

Essa solução "proposta" soa como exercício de abuso de poder de controle, não merecendo de forma alguma prosperar.

\section{V - Conclusão}

Tudo exposto, conclui-se que:

a) A Arbitragem representa potencial vantagens as sociedades que optem por esse meio de solução de litígio, em razão, essencialmente, da agilidade e tecnicidade do procedimento.

b) Somado a esses fatores, a arbitragem como procedimento sigiloso contribui a proteção de segredos industriais, bem como a eventuais especulações que possam ocorrer com os valores mobiliários de sociedades de capital aberto.

c) A Arbitragem fundamenta-se, essencialmente, na manifestação da vontade do indivíduo sob o manto da autonomia da vontade na esfera das obrigações civis e dos direitos patrimoniais disponíveis.

d) A arbitragem como eleição de foro privado solução de conflitos, representa renúncia ao direito da prestação jurisdicional estatal

e) Em sendo renúncia, a clausula compromissoria deverá ser interpretada estritivamente, tanto quando ao seu conteúdo, quanto a forma da manifestação da anuência. 
f) São válidas outras formas, senão apenas a escrita, para caracterização da manifestação da vontade da parte em aderir ao juízo arbitral.

g) A clausula compromissória constitui-se autonomamente ao contrato no qual esta inserida, sendo imune a eventuais vícios que possam contaminar o contrato.

h) Em sendo autônoma, o simples ingresso da parte como sócio ou acionista da sociedade não significa sua intenção em aderir ao pacto arbitral, devendo este se dar por inequívoca manifestação de vontade da parte.

i) Constitui direito essencial do acionista, nos termos da Lei das Sociedades Anônimas o acesso ao judiciário, não podendo este direito ser elidido pela lei ou pelo estatuto, opção que se dará apenas por concordância da parte.

j) Nas sociedades limitadas, o arquivamento de uma alteração do contrato social com a inserção da clausula compromissória assinada por todos os sócios, poderá vincular mesmo aquele que se posicionou contra essa alteração, se este não fizer ressalva, pois a assinatura se presumirá como aceitação.

k) A Arbitragem como renúncia à prestação jurisdicional estatal, diferente da clausula de eleição de foro, acarreta potencial dificuldade no acesso a prestação jurisdicional na hipótese desta ocorrer em Tribunal Arbitral no qual umas das partes não possua condições financeiras de participar do litígio em condições justas, além de suprimir o direito ao duplo grau de jurisdição, devendo por estas, entre outras razões, ser tratada com cautela a fim de se evitar 
que o instituto se torne um meio para o exercício do abuso de poder por sócios ou acionistas majoritários.

1) Entendimento oposto vem sendo dado, até onde se tem informação, na Itália com a edição de norma regulando a matéria. Porém ainda não se tem uma posição consolidada sobre a eficácia dessa norma, principalmente no que tange a sua Corte de Cassação, tribunal de controle constitucional.

m) Em países de tradição do common law se encontrará maior flexibilidade a instauração do juízo arbitral, porém, quando a decisão prescindir de homologação no Superior Tribunal de Justiça para produzir efeitos no território nacional, limite do presente estudo, questões voltadas a ordem pública serão suscitadas, e, este será peça fundamental para que se tenha definido o posicionamento que será adotado no ordenamento jurídico nacional.

\section{Bibliografia}

CARVALHOSA, Modesto. Clausula Compromissória Estatutária. In Logo, Jorge (org.) Reforma da Lei das Sociedades Anônimas. $2^{\text {a }}$ Ed. Rio de Janeiro: Forense., 2000. p. 321-342.

CARVALHOSA, Modesto. Comentários à Lei de Sociedades Anônimas. V. 2. Rio de Janeiro: Saraiva, 2003.

MARTINS, Pedro A. Batista. A arbitragem nas sociedades de responsabilidade limitada in. Reflexões sobre arbitragem: in memoriam do Desembargador Cláudio Vianna de Lima, in. São Paulo, Ed. LTR, p. 133142 
VILELA, Marcelo Dias Gonçalves. Arbitragem no Direito Societário. Belo Horizonte. Mandamentos.

BARBI, Celso Filho. Cumprimento judicial de clausula compromissoria na Lei 93.07/96 e outras intervenções do judiciário na arbitragem privada. Rio de Janeiro: Revista de Direito Mercantil, 1997. p. 89

ASCARELLI, Túlio. Problemas das sociedades anônimas e direito comparado. São Paulo: Saraiva, 1969.

MOREIRA, Daniela Bessone Barbosa. A convenção arbitral em Estatutos e Contratos Sociais. P. 363-391, in ALMEIRA, Ricardo Ramalho. Arbitragem Interna e Internacional - Questões de Doutrina e da Prática. Rio de Janeiro: 2004: Renovar.

CAMPOS, Reglero. El arbitraje: convenio arbitral u lãs caudas de nulidad del laudo en la Ley de 5 de diciembre de 1988. Madrid: Montecorvo, 1991

MIRANDA, Pontes de. Comentários ao Código de Processo Civil. Rio de Janeiro: Ed. Forense, 1977 XV p. 240.

SILVA, José Afonso da. Curso de Direito Constitucional Positivo. 16 Edição. São Paulo: Malheiros, 2003.

NERY JR, Nelson. Princípios do processo civil na constituição federal. São Paulo: Revista dos Tribunais, 1994 - p. 91.

STRENGER, Irineu. Autonomia da Vontade, $-2^{\text {a }}$ Ed. São Paulo: LTR 
SILVA, Eduardo Silva da. Arbitragem e Direito da Empresa - Dogmática e implementação da clausula compromissória. Rio de Janeiro: RT. 2002.

ALVIM, José Eduardo Carreira. Direito Arbitragem. $2^{\text {a }}$ Edição. Rio de Janeiro:Forense.

FERREIRA NETO, Cássio Teles. Arbitragem: Uma Tecnologia Jurídica De Ponta. In Revista de Direito Bancário, do Mercado de Capitais e da Arbitragem. V. 22. São Paulo. P. 361-381.

LIMA, Cláudio Vianna de. Arbitragem a solução. Rio de Janeiro: Forense.

MARTINS, Pedro Batista A.. A arbitragem nas sociedades de responsabilidade limitada. In. Revista de Direito Mercantil. V. 126. São Paulo: Malheiros. P. 59-74

STF, AgR. SE. Rel . Min. Sepulveda Pertence, Brasilia, 12 Dez. 2001.

STJ, SEC 856. Rel. Min. Carlos Alberto Menezes Direito, Brasilia, 18. mai. 2005.

Cour de Cassation - Chambre Civile France - 10 Juillet 1843. 